\title{
A structural investigation of the alkali metal site distribution within bioactive glass using neutron diffraction and multinuclear solid state NMR
}

\author{
Richard A. Martin, ${ }^{* a b}$ Helen L. Twyman, ${ }^{a}$ Gregory J. Rees, ${ }^{c}$ Jodie M. Smith, ${ }^{a}$ \\ Emma R. Barney, ${ }^{d}$ Mark E. Smith, ${ }^{c e}$ John V. Hanna ${ }^{c}$ and Robert J. Newport ${ }^{a}$ \\ Received 25th May 2012, Accepted 25th July 2012 \\ DOI: $10.1039 / \mathrm{c} 2 \mathrm{cp} 41725 \mathrm{a}$
}

The atomic-scale structure of Bioglass and the effect of substituting lithium for sodium within these glasses have been investigated using neutron diffraction and solid state magic angle spinning (MAS) NMR. Applying an effective isomorphic substitution difference function to the neutron diffraction data has enabled the $\mathrm{Na}-\mathrm{O}$ and $\mathrm{Li}-\mathrm{O}$ nearest-neighbour correlations to be isolated from the overlapping $\mathrm{Ca}-\mathrm{O}, \mathrm{O}-(\mathrm{P})-\mathrm{O}$ and $\mathrm{O}-(\mathrm{Si})-\mathrm{O}$ correlations. These results reveal that $\mathrm{Na}$ and $\mathrm{Li}$ behave in a similar manner within the glassy matrix and do not disrupt the short range order of the network former. Residual differences are attributed solely to the variation in ionic radius between the two species. Successful simplification of the $2<r(\AA)<3$ region via the difference method has enabled all the nearest neighbour correlations to be deconvolved. The diffraction data provides the first direct experimental evidence of split $\mathrm{Na}-\mathrm{O}$ nearest-neighbour correlations in these melt quench bioactive glasses, and an analogous splitting of the $\mathrm{Li}-\mathrm{O}$ correlations. The observed correlations are attributed to the metal ions bonded either to bridging or to non-bridging oxygen atoms. ${ }^{23} \mathrm{Na}$ triple quantum MAS (3QMAS) NMR data corroborates the split $\mathrm{Na}-\mathrm{O}$ correlations. The structural sites present will be intimately related to the release properties of the glass system in physiological fluids such as plasma and saliva, and hence to the bioactivity of the material. Detailed structural knowledge is therefore a prerequisite for optimizing material design.

\section{Introduction}

Melt-quenched silicate glasses containing calcium, phosphorous and alkali metals are of great importance due to their ability to bond chemically to bone and to stimulate new bone growth. ${ }^{1,2}$ The original, and by far the most commercially successful, bioactive glass is $45 \mathrm{~S} 5$ Bioglass ${ }^{\circledR}$ developed by Hench and co-workers. ${ }^{1}$ Bioglass has been in clinical use since 1985 and has already been used in over a million cases. ${ }^{3,4}$ The composition of Bioglass is $(\mathrm{CaO})_{26.9}\left(\mathrm{Na}_{2} \mathrm{O}\right)_{24.4}\left(\mathrm{SiO}_{2}\right)_{46.1}\left(\mathrm{P}_{2} \mathrm{O}_{5}\right)_{2.6}(\mathrm{~mol} \%)$. Under physiological conditions the glass slowly dissolves, releasing calcium and phosphorous into solution which can then redeposit as an amorphous calcium phosphate layer. ${ }^{5}$

${ }^{a}$ School of Physical Sciences, Ingram Building, University of Kent, Canterbury, CT2 7NH, UK. E-mail:R.A.Martin@Aston.ac.uk

${ }^{b}$ School of Engineering \& Applied Science and Aston Research Centre for Healthy Ageing, University of Aston, Aston Triangle,

Birmingham, B4 7ET, UK

${ }^{c}$ Department of Physics, University of Warwick, Coventry,

CV4 7AL, UK

${ }^{d}$ Faculty of Engineering, University of Nottingham, Nottingham, $N G 72 R D, U K$

'Vice-Chancellor's Office, University House, University of Lancaster, Lancaster, LA1 $4 Y W, U K$
The mechanism of bone formation onto a bioactive glass, as described by Hench, is a complex multi-step process. ${ }^{6}$ The first five steps are given below:

Stage 1. Ion exchange of the alkali and alkali earth elements, typically $\mathrm{Na}^{+}$and $\mathrm{Ca}^{2+}$, from the glass with $\mathrm{H}^{+}$ from the surrounding physiological fluid:

$$
\mathrm{Si}-\mathrm{O}-\mathrm{Na}+\mathrm{H}_{2} \mathrm{O} \rightarrow \mathrm{Si}-\mathrm{OH}+\mathrm{Na}^{+}{ }_{(\mathrm{aq})}+\mathrm{OH}^{-}
$$

Stage 2. The $\mathrm{Si}-\mathrm{O}-\mathrm{Si}$ are broken to form silanols, releasing soluble $\mathrm{Si}(\mathrm{OH})_{4}$ to the surrounding solution:

$$
\mathrm{Si}-\mathrm{O}-\mathrm{Si}+\mathrm{H}_{2} \mathrm{O} \rightarrow \mathrm{Si}-\mathrm{OH}+\mathrm{OH}-\mathrm{Si}
$$

The first two stages are highly dependent on the overall composition and type of glass (e.g. melt quench vs. sol-gel).

Stage 3. High concentrations of silanol groups (formed during stage 2) are present at the glass : solution interface, and begin to re-polymerize to form a silica-rich layer at the glass surface as follows:<smiles></smiles> 
Stage $4 . \mathrm{Ca}^{2+}$ and $\mathrm{PO}_{4}{ }^{3-}$ groups migrate from the surrounding aqueous medium to the surface, through the silica-rich layer, and precipitate to form a $\mathrm{Ca}-\mathrm{P}_{2} \mathrm{O}_{5}$ rich film on top of the silica layer. This results in the growth of an amorphous calcium phosphate layer. ${ }^{7}$

Stage 5. The amorphous calcium phosphate layer begins to incorporate $\mathrm{OH}^{-}$and/or $\mathrm{CO}_{3}{ }^{2-}$ anions from the surrounding solutions and crystallizes to form a mixed hydroxycarbonate apatite (HCA) layer. The formation of this biologically active HCA layer is believed to be a prerequisite for glasses and glass ceramics to bond to host tissue.

The glass structure, composition and species of ions present strongly influence its chemical durability (i.e. its dissolution in physiological fluids). In turn, the ionic strength and chemical nature of cations present will effect protein-protein interactions. ${ }^{8,9}$

Each of the components plays a specific role in the dissolution of the glass and the eventual formation of hydroxyapatite. The silica glass includes $\mathrm{Ca}^{2+}, \mathrm{P}^{5+}$ and $\mathrm{Na}^{+}$ions which, via their effect on the glass network structure, control its degradation rate. Calcium and phosphorous dissolve from the glass to create a high concentration solution at the glass : physiological fluid interface, which can then redeposit as an amorphous calcium phosphate - a precursor to the formation of hydroxyapatite. In addition, when $\mathrm{P}_{2} \mathrm{O}_{5}$ dissolves it also creates acidic species which help to reduce the $\mathrm{pH}$ increase caused by the dissolution of $\mathrm{Ca}^{2+}$ and $\mathrm{Na}^{+}$ions. ${ }^{10}$ Furthermore, if suitably controlled via the glass composition, the release rate of $\mathrm{Ca}, \mathrm{P}$ and $\mathrm{Si}$ can stimulate gene transcription in osteoblasts. ${ }^{11}$ The addition of sodium also lowers the melt temperature and $\mathrm{Ca}$ extends the range over which the glass may be worked, helping with glass formation. However, the exact biological role of $\mathrm{Na}$ within these glasses is less clear, in fact most bioactive sol-gel derived glasses are sodium free. ${ }^{12-18}$ Sodium may therefore adopt a primarily structural role within these glasses and be used, in effect, to control the key dissolution rates of $\mathrm{Ca}, \mathrm{P}$ and $\mathrm{Si}$. However, the precise nature of the local environment surrounding $\mathrm{Na}$ ions within these glasses has remained unquantified.

In order to be able to model and predict the behaviour of these materials, and ultimately improve their design, it is necessary to understand the local structure of the glasses. Consequently, the atomic-scale structure of bioactive glasses and its effect on chemical durability and bioactivity has been the focus of much attention. ${ }^{19-23}$ However the addition of an alkali metal, an alkaline-earth metal as well as a second network former in the form of phosphorous means that the generation of a structural model of Bioglass and its derivatives is challenging. This is particularly true for the sodium environment given that sodium has a low atomic number and its pair correlations are easily masked in a total X-ray diffraction pattern; furthermore, it is mono-isotopic and the advanced structural method of isotopic substitution applied to neutron diffraction, which has been employed to study the local calcium environment, ${ }^{5}$ is therefore not possible. Although significant progress has been made in understanding the structure of Bioglass by employing molecular dynamic simulations, ${ }^{20-22,24,25}$ experimental techniques have to date been unable to fully deconvolve the complex overlapping structural features. $^{26}$
Cations with the same valence and a similar charge-to-size ratio can readily be substituted within the glass matrix; for example, sodium can be replaced with lithium ${ }^{27}$ or potassium. $^{28,29}$ It has been suggested that $\mathrm{Na}-\mathrm{Ca}$ silicate glasses show a non-random distribution of cations, with a preference for $\mathrm{Ca}-\mathrm{O}-\mathrm{Na}$ hetero-bonds at the expense of $\mathrm{Ca}-\mathrm{O}-\mathrm{Ca}$ and $\mathrm{Na}-\mathrm{O}-\mathrm{Na}$ homo-bonds. ${ }^{30}$ It is therefore important to understand the role alkali metals play in the local environment surrounding calcium ions and determine whether substituting $\mathrm{Li}$ for $\mathrm{Na}$ affects the $\mathrm{Ca}-\mathrm{O}$ environment. Recently, by substituting strontium for calcium within these glasses, significant progress has been made on the understanding of the local environment surrounding the calcium ions. ${ }^{31}$ We have therefore chosen to investigate the influence of substituting $\mathrm{Li}$ for $\mathrm{Na}$ in the glass series $\left(\mathrm{SiO}_{2}\right)_{46.1}\left(\mathrm{P}_{2} \mathrm{O}_{5}\right)_{2.6^{-}}$ $(\mathrm{CaO})_{26.9}\left(\mathrm{Na}_{2} \mathrm{O}\right)_{24.4-x}\left(\mathrm{Li}_{2} \mathrm{O}\right)_{x}$ (where $\left.x=0,12.2,24.4\right)$ in terms of the glass' atomic-scale structural characteristics using neutron diffraction and multinuclear ${ }^{7} \mathrm{Li},{ }^{23} \mathrm{Na},{ }^{29} \mathrm{Si}$ and ${ }^{31} \mathrm{P}$ solid state magic angle spinning (MAS) NMR.

\section{Experimental}

\subsection{Sample preparation}

Melt-quenched glass samples were prepared using $\mathrm{SiO}_{2}$ (Alfa Aesar, 99.5\%), $\mathrm{P}_{2} \mathrm{O}_{5}$ (Sigma-Aldrich, 98.5\%), $\mathrm{CaCO}_{3}$ (Alfa Aesar, 99.95-100.5\%) and $\mathrm{Na}_{2} \mathrm{CO}_{3}$ (Sigma-Aldrich, $99.5+$ $\%$ ), and/or $\mathrm{Li}_{2} \mathrm{CO}_{3}$ (Sigma-Aldrich, 99.99\%). The precursors were heated in a platinum crucible to $1400{ }^{\circ} \mathrm{C}$ at $10{ }^{\circ} \mathrm{C} \mathrm{min}{ }^{-1}$ and held at temperature for $1.5 \mathrm{~h}$. The molten glass was then poured into a pre-heated graphite mould $\left(350{ }^{\circ} \mathrm{C}\right)$ and annealed at this temperature overnight before being allowed to cool slowly to room temperature. ${ }^{7}$ The batch compositions of the three glasses prepared were $\left(\mathrm{SiO}_{2}\right)_{46.1}(\mathrm{CaO})_{26.9}\left(\mathrm{P}_{2} \mathrm{O}_{5}\right)_{2.6}$ $\left(\mathrm{Na}_{2} \mathrm{O}\right)_{24.4-x}\left(\mathrm{Li}_{2} \mathrm{O}\right)_{x}$ (where $x=0,12.2$ and 24.4) and they are labelled ${ }^{\mathrm{Na}} \mathrm{Bio},{ }^{\mathrm{NaLi}} \mathrm{Bio}$ and ${ }^{\mathrm{Li}} \mathrm{Bio}$ respectively. The macroscopic densities of the glass samples were determined by helium pycnometry using a Quantachrome Multipycnometer.

\subsection{Neutron diffraction method and analysis}

Neutron diffraction spectra were collected using the GEM diffractometer at the ISIS spallation neutron source at the Rutherford Appleton Laboratory, UK. ${ }^{32}$ The coarsely ground samples were held at ambient temperature in a cylindrical vanadium container of $8.3 \mathrm{~mm}$ internal diameter and $0.025 \mathrm{~mm}$ wall thickness. Interference patterns were collected for each of the samples as well as data for a vanadium rod of $8 \mathrm{~mm}$ diameter and the empty GEM instrument in order to perform the appropriate corrections. The data reduction and corrections were performed using the program GUDRUN. ${ }^{32}$ These corrections involve the removal of background scattering, normalisation, correction for absorption, inelastic and multiple scattering effects and subtraction of the self-scattering term. ${ }^{32}$ Following these corrections, the resultant coherent scattering intensity, $i(Q)$, is defined by

$$
i(Q)=\sum_{\mathrm{i}} \sum_{\mathrm{j}} c_{\mathrm{i}} c_{\mathrm{j}} b_{\mathrm{i}} b_{\mathrm{j}}\left[p_{\mathrm{ij}}(Q)-1\right]
$$

where $c_{\mathrm{i}}, c_{\mathrm{j}}, b_{\mathrm{i}}$ and $b_{\mathrm{j}}$ represent the atomic concentration and coherent scattering length of the chemical species $i$ and $j$ 
respectively, and $p_{\mathrm{ij}}(Q)$ is the pair correlation function. Fourier transformation of $i(Q)$ generates the total correlation function, $T(r)$, given by

$$
T(r)=T^{0}(r)+\frac{2}{\pi} \int_{0}^{\infty} Q i(Q) M(Q) \sin (Q r) \mathrm{d} Q
$$

where $M(Q)$ is a Lorch window function that mitigates the effect of the finite maximum experimentally attainable value of $Q$, and $T^{0}(r)$ is the average density term given by:

$$
T^{0}(r)=4 \pi r \rho^{0}\left(\sum_{\mathrm{i}} c_{\mathrm{i}} b_{\mathrm{i}}\right)^{2}
$$

where $r$ is the distance from an arbitrary atom at the origin and $\rho^{0}$ is the number density.

Structural information can be obtained by modelling the real-space correlation functions. Pair functions are generated in $Q$-space and Fourier transformed to allow comparison with the experimental data in real-space. The pair functions are given by:

$$
p_{\mathrm{ij}}(Q)_{\mathrm{ij}}=\frac{N_{\mathrm{ij}} w_{\mathrm{ij}}}{c_{\mathrm{j}}} \frac{\sin Q r_{\mathrm{ij}}}{Q r} \exp \left[\frac{-Q^{2} \sigma_{\mathrm{ij}}^{2}}{2}\right]
$$

where $N_{\mathrm{ij}}, r_{\mathrm{ij}}$ and $\sigma_{\mathrm{ij}}$ represent the coordination number, atomic separation and disorder parameters respectively. The weighting factor $w_{\mathrm{ij}}$ is given by:

$$
\begin{gathered}
w_{\mathrm{ij}}=2 c_{\mathrm{i}} c_{\mathrm{j}} b_{\mathrm{i}} b_{\mathrm{j}} \quad \text { if } \mathrm{i} \neq \mathrm{j} \\
w_{\mathrm{ij}}=c_{\mathrm{i}}{ }^{2} b_{\mathrm{i}}{ }^{2} \quad \text { if } \mathrm{i}=\mathrm{j}
\end{gathered}
$$

The method of isomorphic substitution was applied to the neutron diffraction data. ${ }^{33,34}$ If three total structure factors ${ }^{\mathrm{Na}} i(Q),{ }^{\mathrm{NaLi}} i(Q)$ and ${ }^{\mathrm{Li}} i(Q)$ are measured corresponding to scattering lengths $b_{\mathrm{Na}}>b_{\mathrm{NaLi}}>b_{\mathrm{Li}}$ then those correlations not involving the sodium or lithium ion can be eliminated by subtracting two total structure factors to give a first order difference function such as ${ }^{\mathrm{Na}-\mathrm{Li}} \Delta i(Q)={ }^{\mathrm{Na}} i(Q)-{ }^{\mathrm{Li}} i(Q)$. The addition of the third total structure factor enables three separate first order difference functions to be determined $\left({ }^{\mathrm{Na}-\mathrm{Li}} \Delta i(Q),{ }^{\mathrm{Na}-\mathrm{NaLi}} \Delta i(Q)\right.$ and $\left.{ }^{\mathrm{NaLi}-\mathrm{Li}} \Delta i(Q)\right)$ in order to check the reliability/mutual consistency of the derived data sets. Full details on the method of isomorphic substitution are given by Martin et $a l .{ }^{33}$ The assumption of isomorphism is valid over the short range order, however due to the size difference between the $\mathrm{Na}^{+}$and $\mathrm{Li}^{+}$ions the medium and extended range order is not assumed to be isomorphic. The diffraction data is therefore only modelled up to $3 \AA$.

\subsection{Solid state NMR}

${ }^{7} \mathrm{Li}(I=3 / 2)$ MAS NMR data were acquired at ambient temperatures using a Varian Infinity Plus-300 spectrometer (7.05 T, Larmor frequency of $116.59 \mathrm{MHz}$ ) and a Bruker $2.5 \mathrm{~mm}$ HX double-air-bearing probe MAS in which spinning frequencies of $27.5 \mathrm{kHz}$ were implemented. A $2 \mu \mathrm{s} \pi / 2$ nonselective (or solution) pulse time was calibrated on a primary reference solution of $9.7 \mathrm{M} \mathrm{LiCl}_{(\mathrm{aq})}\left(\delta_{\text {iso }} 0.0 \mathrm{ppm}\right)$, from which a selective (or solids) $\pi / 4$ pulse time of $1 \mu$ s was used in the measurements. A recycle delay of $2 \mathrm{~s}$ was used and 16 transients were acquired for each data set. ${ }^{23} \mathrm{Na}(I=3 / 2)$ MAS data were acquired using a Bruker AvanceII-600 spectrometer (14.1 T, Larmor frequency of $158.55 \mathrm{MHz}$ ). These measurements were undertaken using a Bruker $4 \mathrm{~mm} \mathrm{HX}$ double-air-bearing probe MAS in which spinning frequencies of $12.5 \mathrm{kHz}$ were implemented. A $5 \mu \mathrm{s} \pi / 2$ non-selective (or solution) pulse time was calibrated on a secondary solid reference of $\mathrm{NaCl}$ $\left(\delta_{\text {iso }} 7.2 \mathrm{ppm}\right)$, from which a selective (or solids) $\pi / 4$ pulse time of $1.25 \mu \mathrm{s}$ was used in the measurements; recycle delays of $5 \mathrm{~s}$ were used. All data are referenced against the primary solution reference of $0.1 \mathrm{M} \mathrm{NaCl}_{(\mathrm{aq})}\left(\delta_{\text {iso }} 0 \mathrm{ppm}\right)$.

Corresponding ${ }^{29} \mathrm{Si}(I=1 / 2)$ data were acquired on a Varian Infinity Plus 300 system $(7.05 \mathrm{~T}$, Larmor frequency of $59.58 \mathrm{MHz}$ ) using a Bruker $\mathrm{HX} 7 \mathrm{~mm}$ double-air-bearing probe in which spinning frequencies of $5 \mathrm{kHz}$ were attained. All ${ }^{29} \mathrm{Si}$ spectra were referenced to a secondary solid kaolinite reference which is located at $\delta_{\text {iso }}-92 \mathrm{ppm}$ with respect to the primary reference of TMS $\left(\delta_{\text {iso }} 0\right.$ ppm, $\left.298 \mathrm{~K}\right){ }^{35}$ These data were acquired using single pulse methods with a $\pi / 4$ pulse time of $2.5 \mu \mathrm{s}$ and a recycle delay of $30 \mathrm{~s}$. The ${ }^{31} \mathrm{P}(I=1 / 2)$ MAS data were measured using a Bruker DSX-400 (9.4 T, Larmor frequency $161.9 \mathrm{MHz}$ ) and a Bruker $3.2 \mathrm{~mm} \mathrm{HX}$ doubleair-bearing probe which enabled spinning frequencies of $12.5 \mathrm{kHz}$. ${ }^{31} \mathrm{P}$ spectra were indirectly referenced to a secondary reference of ammonium dihydrogen phosphate ( $\delta_{\text {iso }} 0.95 \mathrm{ppm}$ ) with $85 \%$ $\mathrm{H}_{3} \mathrm{PO}_{4(\mathrm{aq})}$ being used as the primary reference $\left(\delta_{\text {iso }} 0.0 \mathrm{ppm}\right)$. These data were also acquired using single pulse methods with a $\pi / 4$ pulse time of $1.25 \mu$ s and a recycle delay of $30 \mathrm{~s}^{31}$

${ }^{23} \mathrm{Na}$ triple quantum MAS (3QMAS) data were measured on a Bruker AvanceII-600 spectrometer at $158.55 \mathrm{MHz}$ using a double resonance Bruker $4.0 \mathrm{~mm} \mathrm{HX}$ probe and a MAS frequency of $12.5 \mathrm{kHz}$. 3QMAS experiments were recorded using a four pulse Z-filter experiment. ${ }^{36,37}$ A selective excitation pulse $(\sim 3 \pi / 2)$ of $4.5 \mu$ s and conversion pulse $(\sim \pi / 2)$ of $1.3 \mu$ s conversion pulse were followed by two soft non-selective $\pi / 2$ pulses of $25 \mu \mathrm{s}$, and the recycle delay was $5 \mathrm{~s}$.

\section{Results and discussion}

The glasses were transparent and homogenous with densities of 2.73, 2.70 and $2.66 \mathrm{~g} \mathrm{~cm}^{-3}$ for ${ }^{\mathrm{Na}} \mathrm{Bio},{ }^{\mathrm{NaLi}} \mathrm{Bio}$ and ${ }^{\mathrm{Li}} \mathrm{Bio}$ respectively. The increase in density being directly attributed to the increased atomic weight of $\mathrm{Na}$ compared to $\mathrm{Li}$.

The neutron diffraction interference functions, $i(Q)$, for ${ }^{\mathrm{Na} B i o},{ }^{\mathrm{NaLi}}$ Bio and the ${ }^{\mathrm{Li}}$ Bio samples are shown in Fig. 1 and the first order difference functions, $\Delta i(Q)$, are shown in Fig. 2. Fig. 3 shows the corresponding real space pairwise correlation data $T(r)$ obtained by Fourier transforming the $i(Q)$ functions given in Fig. 1, while Fig. 4 shows the real space pairwise correlation data $\Delta T(r)$ obtained by Fourier transforming the $\Delta i(Q)$ functions given in Fig. 2. The weighting factors for each of the total structure factors and difference functions are given in Table 1. The first feature (shortest $r$-space distance) in $T(r)$, Fig. 3, corresponds to $\mathrm{P}-\mathrm{O}$ and Si-O correlations $(\sim 1.6 \AA)$, the second feature $(\sim 2.1$ to $2.9 \AA)$ contains overlapping $\mathrm{O}-(\mathrm{P})-\mathrm{O}, \mathrm{O}-(\mathrm{Si})-\mathrm{O}, \mathrm{Ca}-\mathrm{O}$ and $\mathrm{Na}-\mathrm{O}$ and/or $\mathrm{Li}-\mathrm{O}$ correlations; it is therefore not usually possible to deconvolve these correlations from the real space total diffraction data. However, those correlations that do not contain $\mathrm{Na}$ or Li cancel during the formation of the first order difference functions (Table 1). This is confirmed by the notable absence of the $\mathrm{P}-\mathrm{O}$ and $\mathrm{Si}-\mathrm{O}$ peaks at $\sim 1.6 \AA$ in the $\Delta T(r)$ functions, 


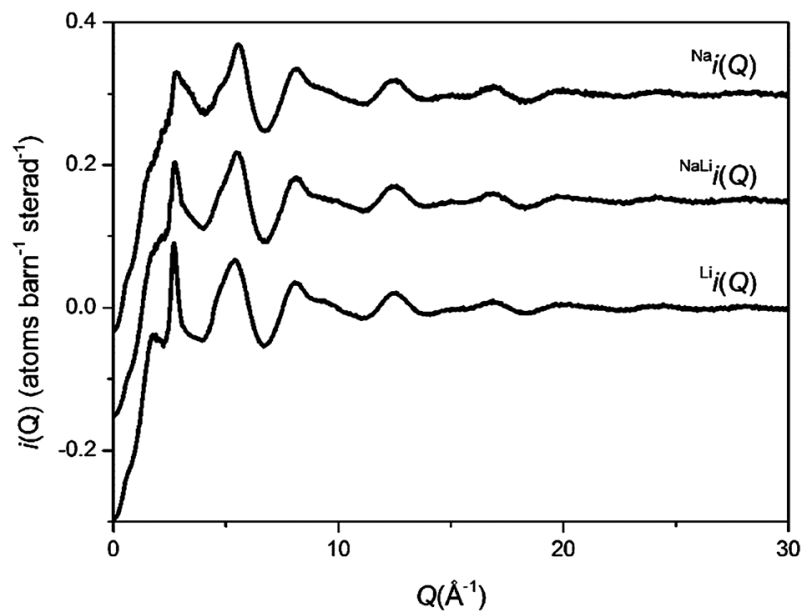

Fig. $1 Q$-space interference functions, $i(Q)$, for ${ }^{\mathrm{Na}} \mathrm{Bio},{ }^{\mathrm{NaLi}} \mathrm{Bio}$ and ${ }^{\mathrm{Li}}$ Bio. The $Q$-space data extends to $50 \AA^{-1}$ but only $0<Q\left(\AA^{-1}\right)<30$ is shown for clarity.

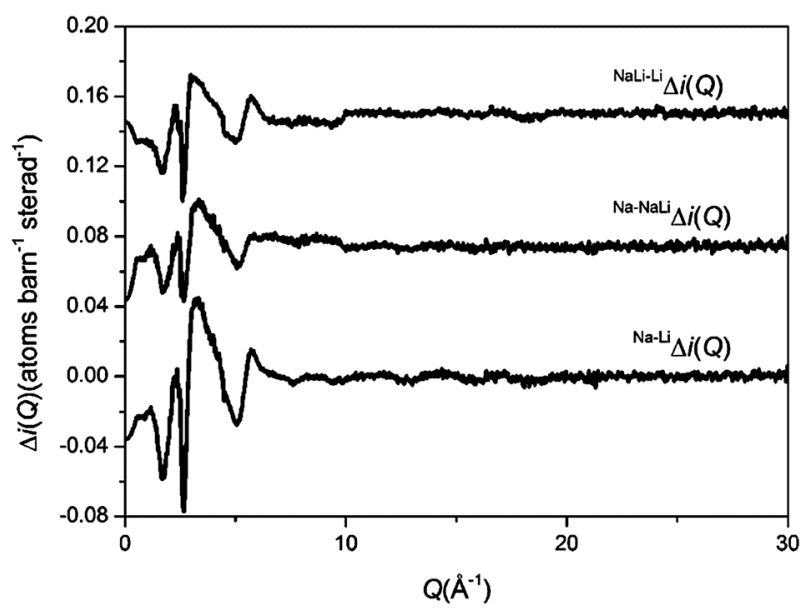

Fig. $2 Q$-space interference difference functions, $\Delta i(Q)$, for ${ }^{\mathrm{Na}-\mathrm{Li}} \Delta i(Q)$, ${ }^{\mathrm{Na}-\mathrm{NaLi}} \Delta i(Q)$ and ${ }^{\mathrm{NaLi}-\mathrm{Li}} \Delta i(Q)$.

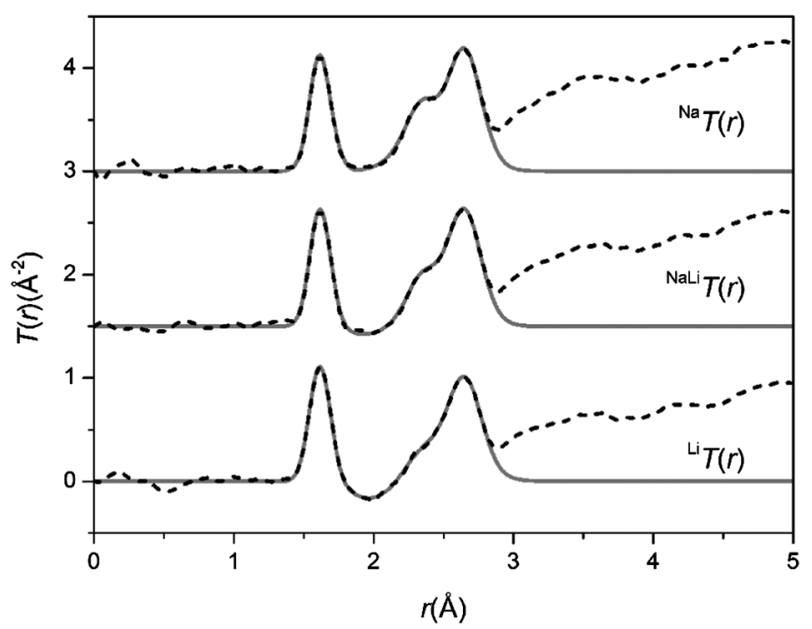

Fig. 3 The real-space data for the total diffraction patterns, $T(r)$, the data sets are offset for clarity. The broken curves represent the experimental data and the solid curves are the resultant fits.

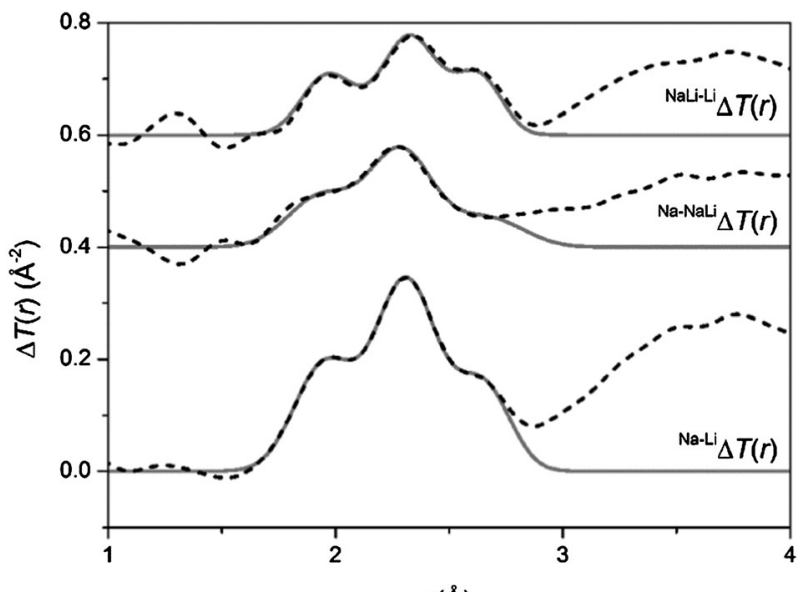

$r(\AA)$

Fig. 4 The real-space data for the difference functions, $\Delta T(r)$. The broken curves represent the experimental data and the solid curves are the resultant fits.

illustrated in Fig. 4. Similarly, the $\mathrm{O}-(\mathrm{P})-\mathrm{O}, \mathrm{O}-(\mathrm{Si})-\mathrm{O}$ and $\mathrm{Ca}-\mathrm{O}$ correlations have been eliminated during the formation of the difference functions. Of the remaining correlations present, the first (shortest separation in $r$-space) correlations will correspond to nearest neighbours $\mathrm{Na}-\mathrm{O}$ and $\mathrm{Li}-\mathrm{O}$. The second nearest neighbours such as $\mathrm{Na}-(\mathrm{O})-\mathrm{Na}, \mathrm{Na}-(\mathrm{O})-\mathrm{Li}$, $\mathrm{Na}-(\mathrm{O})-\mathrm{P}, \mathrm{Na}-(\mathrm{O})-\mathrm{Si}, \mathrm{Li}-(\mathrm{O})-\mathrm{Li}, \mathrm{Li}-(\mathrm{O})-\mathrm{P}$ and $\mathrm{Li}-(\mathrm{O})-\mathrm{Si}$ are not expected to occur until beyond $2.8 \AA$. The first order difference functions may therefore be modelled exclusively using $\mathrm{Na}-\mathrm{O}$ and $\mathrm{Li}-\mathrm{O}$ correlations. The data was fitted using the NXFit program developed by Moss. ${ }^{38}$ It is apparent from Fig. 4 that it is not possible to fit the data using a single $\mathrm{Na}-\mathrm{O}$ and $\mathrm{Li}-\mathrm{O}$ correlation, so a two-peak fitting process was employed.

The output fit parameters for the ${ }^{\mathrm{Na}-\mathrm{Li}} \Delta i(Q)$ first order difference function are given in Table 2. The ${ }^{\mathrm{Na}-\mathrm{Li}} \Delta i(Q)$ first order difference function has the highest signal : noise ratio, being approximately twice that of the other first order difference functions and therefore provides the most accurate and reliable fit parameters. To ensure the results are self-consistent the other difference functions were modelled using the ${ }^{\mathrm{Na}-\mathrm{Li}} \Delta i(Q)$ output parameters as their initial input values for the fitting program and the model was subject to constraints. The resultant output parameters are given in Table 2. This confirms that all the data sets are in agreement and are selfconsistent.

Bond valence parameters developed by Brown and Altermatt ${ }^{39}$ may be used to further verify the $\mathrm{Na}-\mathrm{O}$ and $\mathrm{Li}-\mathrm{O}$ parameters obtained from the neutron diffraction fitting. According to the bond valence approach $V_{\mathrm{i}}$, the oxidation state of cation $i$, is given by

$$
V_{\mathrm{i}}=\sum_{\mathrm{j}} v_{\mathrm{ij}}=\sum_{\mathrm{j}} \exp \left[\frac{R_{\mathrm{ij}}-r_{\mathrm{ij}}}{B}\right]
$$

where $v_{\mathrm{ij}}$ is the valence of the bond between atom $\mathrm{i}$ and $\mathrm{j}, B$ is an empirical constant (0.37) and $R_{\mathrm{ij}}$ is bond valence parameter for the atom pair i,j as determined by Brown and Altermatt: ${ }^{39}$ $R_{\mathrm{NaO}}$ and $R_{\mathrm{LiO}}$ values are given as 1.803 and 1.466 respectively. Applying eqn (7) to the fit parameters given in Table 2 
Table 1 Weighting factors $w_{\alpha \beta}$ calculated using eqn (5) and (6), (barn $=10^{-28} \mathrm{~m}^{2}$ )

\begin{tabular}{|c|c|c|c|c|c|c|}
\hline & ${ }^{\mathrm{Na}} T(r)$ & ${ }^{\mathrm{NaLi}} T(r)$ & ${ }^{\mathrm{Li}} T(r)$ & ${ }^{\mathrm{Na}-\mathrm{Li}} \Delta T(r)$ & ${ }^{\mathrm{Na}-\mathrm{NaLi}} \Delta T(r)$ & ${ }_{\mathrm{NaLi}-\mathrm{Li}} \Delta T(r)$ \\
\hline$t_{\mathrm{Na}-\mathrm{O}}(r)$ & 40.03 & 20.02 & - & 40.03 & 20.02 & 20.02 \\
\hline$t_{\mathrm{Na}-\mathrm{Si}}(r)$ & 8.43 & 4.22 & - & 8.43 & 4.22 & 4.22 \\
\hline$t_{\mathrm{Na}-\mathrm{Ca}}(r)$ & 5.57 & 2.79 & - & 5.57 & 2.79 & 2.79 \\
\hline$t_{\mathrm{Na}-\mathrm{P}}(r)$ & 1.18 & 0.59 & - & 1.18 & 0.59 & 0.59 \\
\hline$t_{\mathrm{Na}-\mathrm{Na}}(r)$ & 3.90 & 0.98 & - & 3.90 & 2.93 & 0.98 \\
\hline$t_{\mathrm{Na}-\mathrm{Li}}(r)$ & - & -1.02 & - & 0.00 & 1.02 & -1.02 \\
\hline$t_{\mathrm{Li}-\mathrm{O}}(r)$ & - & -10.48 & -20.95 & 20.95 & 10.48 & 10.48 \\
\hline$t_{\mathrm{Li}-\mathrm{Si}}(r)$ & - & -2.21 & -4.41 & 4.41 & 2.21 & 2.21 \\
\hline$t_{\mathrm{Li}-\mathrm{Ca}}(r)$ & - & -1.46 & -2.92 & 2.92 & 1.46 & 1.46 \\
\hline$t_{\mathrm{Li}-\mathrm{P}}(r)$ & - & -0.31 & -0.62 & 0.62 & 0.31 & 0.31 \\
\hline$t_{\mathrm{Li}-\mathrm{Li}}(r)$ & - & 0.27 & 1.07 & -1.07 & -0.27 & -0.80 \\
\hline$t_{\mathrm{Si}-\mathrm{O}}(r)$ & 43.23 & 43.23 & 43.23 & - & - & - \\
\hline$t_{\mathrm{P}-\mathrm{O}}(r)$ & 6.03 & 6.03 & 6.03 & - & - & - \\
\hline$t_{\mathrm{O}-\mathrm{O}}(r)$ & 102.62 & 102.62 & 102.62 & - & - & - \\
\hline$t_{\mathrm{Ca}-\mathrm{O}}(r)$ & 28.57 & 28.57 & 28.57 & - & - & - \\
\hline$t_{\mathrm{Ca}-\mathrm{Si}}(r)$ & 6.02 & 6.02 & 6.02 & - & - & - \\
\hline$t_{\mathrm{Ca}-\mathrm{P}}(r)$ & 0.84 & 0.84 & 0.84 & - & - & - \\
\hline$t_{\mathrm{Ca}-\mathrm{Ca}}(r)$ & 1.99 & 1.99 & 1.99 & - & - & - \\
\hline$t_{\mathrm{Si}-\mathrm{P}}(r)$ & 1.27 & 1.27 & 1.27 & - & - & - \\
\hline$t_{\mathrm{Si}-\mathrm{Si}}(r)$ & 4.55 & 4.55 & 4.55 & - & - & - \\
\hline$t_{\mathrm{P}-\mathrm{P}}(r)$ & 0.09 & 0.09 & 0.09 & - & - & - \\
\hline
\end{tabular}

Table 2 Structural parameters obtained by fitting the $\Delta T(r)$ difference functions

\begin{tabular}{|c|c|c|c|c|c|c|c|c|c|}
\hline & \multicolumn{3}{|l|}{${ }^{\mathrm{Na}-\mathrm{Li}} \Delta T(r)$} & \multicolumn{3}{|l|}{$\stackrel{\mathrm{Na}-\mathrm{NaLi}}{{ }^{2}} \Delta T(r)$} & \multicolumn{3}{|l|}{${ }^{\mathrm{NaLi}-\mathrm{Li}} \Delta T(r)$} \\
\hline & $r(\AA)( \pm 0.02)$ & $N( \pm 0.2)$ & $\sigma(\AA)( \pm 0.04)$ & $r(\AA)( \pm 0.02)$ & $N( \pm 0.2)$ & $\sigma(\AA)( \pm 0.04)$ & $r(\AA)( \pm 0.02)$ & $N( \pm 0.2)$ & $\sigma(\AA)( \pm 0.04)$ \\
\hline $\mathrm{Li}-\mathrm{O}$ & 1.95 & 3.0 & 0.11 & 1.93 & 3.1 & 0.13 & 1.96 & 2.9 & 0.09 \\
\hline $\mathrm{Li}-\mathrm{O}$ & 2.27 & 1.6 & 0.21 & 2.25 & 1.7 & 0.17 & 2.29 & 1.5 & 0.24 \\
\hline $\mathrm{Na}-\mathrm{O}$ & 2.31 & 3.1 & 0.12 & 2.29 & 3.0 & 0.12 & 2.33 & 3.1 & 0.10 \\
\hline $\mathrm{Na}-\mathrm{O}$ & 2.65 & 1.6 & 0.10 & 2.67 & 1.5 & 0.14 & 2.63 & 1.7 & 0.07 \\
\hline
\end{tabular}

results in $V_{\mathrm{NaO}}$ and $V_{\mathrm{LiO}}$ values of 0.95 and 0.99 respectively. These values are therefore in good agreement, within experimental error, of the monovalent charge expected for alkali-metals.

A split $\mathrm{Na}-\mathrm{O}$ peak has not been directly observed before in bioactive glasses, although this has been predicted in molecular dynamics (MD) simulations for sodium silicates and for Bioglass. ${ }^{40-42}$ However, MD results for Bioglass are dependent upon the type of simulation employed. For example, classical MD simulations using Shell Models, Rigid Ion Models and Car-Parrinello simulations predicted $\mathrm{Na}-\mathrm{O}_{\mathrm{NB}}$ distances of 2.33, 2.38 and $2.28 \AA$ respectively with between 4.0 and 4.6 oxygen atoms surround each sodium atom, whilst $\mathrm{Na}-\mathrm{O}_{\mathrm{B}}$ distances ranging between 2.45 and $2.52 \AA$ were reported with $\mathrm{Na}-\mathrm{O}$ coordination numbers between 1.0 and $1.6^{41} \mathrm{Na}-\mathrm{O}$ coordination numbers reported in MD simulations are higher than presented in this study. However, it is important to note that the majority of MD simulations report $\mathrm{Na}-\mathrm{O}$ coordination numbers using a cut-off distance of $\sim 3.1$ to $3.3 \AA$. For example, Tilocca presents $\mathrm{Na}-\mathrm{O}$ coordination numbers between 5.4 and 5.6 for $45 \mathrm{~S} 5$ bioglass using a cut-off of $3.1 \AA^{43}$ whilst Xiang and $\mathrm{Du}$ present a $\mathrm{Na}-\mathrm{O}$ coordination number of 5.7 using a cut-off of $3.34 \AA{ }^{20}$ In the present study the local minima occurs at less than $3 \AA$ (Fig. 4). These correlations are however very broad and the minima does not return to zero, thus by selecting a longer cut-off a larger coordination number would be obtained. It is clear though that the $\mathrm{Na}-\mathrm{O}$ environment is very disordered and that further correlations appear at distances greater than previously thought. Previous diffraction data reported a Na-O coordination number of six at $2.35 \AA{ }^{26}$ it is now clear that the $\mathrm{RMC}$ model employed during this study underestimated the $\mathrm{O}-(\mathrm{Si})-\mathrm{O}$ coordination number, this in turn led to this overestimation of the $\mathrm{Na}-\mathrm{O}$ coordination number due to the overlapping nature of these correlations. The $\mathrm{Na}-\mathrm{O}_{\mathrm{NB}}$ coordination number of 3.0 presented in this study is however in excellent agreement with previous neutron diffraction and MD results for sodium silicate glasses where values of $3.0 \pm 0.5$ were reported for the first symmetric peak in $T(r){ }^{44,45}$ In crystalline $\mathrm{Na}_{2} \mathrm{CaSi}_{2} \mathrm{O}_{6}$ a wide range of $\mathrm{Na}-\mathrm{O}$ distances are reported: $2.30-2.90 \AA .{ }^{46}$ Similarly a large range of $\mathrm{Na}-\mathrm{O}$ distances have been reported for MD simulations. Existing simulation models are able to accurately reproduce either the $\mathrm{Na}-\mathrm{O}_{\mathrm{B}}$ or $\mathrm{Na}-\mathrm{O}_{\mathrm{NB}}$ distance but can struggle to reproduce both distances simultaneously. For example, Pedone et al. report $\mathrm{Na}-\mathrm{O}_{\mathrm{NB}}$ and $\mathrm{Na}-\mathrm{O}_{\mathrm{B}}$ distances of 2.32 and $2.42 \AA$ for 45S5 bioglass, ${ }^{47}$ whilst Malavasi et al. report $\mathrm{Na}-\mathrm{O}_{\mathrm{NB}}$ and $\mathrm{Na}-\mathrm{O}_{\mathrm{B}}$ distances of $\sim 2.42$ and $2.62 \AA .{ }^{42}$ This study presents experimental distances of $\sim 2.30$ and $2.64 \AA$ for $\mathrm{Na}-\mathrm{O}_{\mathrm{NB}}$ and $\mathrm{Na}-\mathrm{O}_{\mathrm{B}}$ correlations respectively. The $\mathrm{Na}-\mathrm{O}$ correlations reported here are therefore within the expected values based on existing simulations and experimental data on crystalline analogues. The $\mathrm{Li}-\mathrm{O}$ values are in similarly good agreement with values reported for crystalline Li-silicates and $\mathrm{Na}-\mathrm{Li}$-silicates. Hesse reported 3 oxygen atoms around $\mathrm{Li}$ at 
1.94 to $1.96 \AA$ with additional oxygen atoms at 2.17 and $2.73 \AA$ for crystalline $\mathrm{Li}_{2} \mathrm{SiO}_{3}{ }^{48}$ Lithium therefore occupies a tetrahedral $\left[\mathrm{LiO}_{4}\right]$ coordination where one of the $\mathrm{Li}-\mathrm{O}$ has a very long bond length, the additional oxygen is associated with a neighbouring tetrahedral unit. The results are also in broad agreement with $\mathrm{MD}$ simulations e.g. Pedone et al. report a nearest neighbour $\mathrm{Li}-\mathrm{O}_{\mathrm{NB}}$ distance of $1.97 \AA$ and a coordination number of 3.0 in lithium silicates $\left(30 \mathrm{~mol} \% \mathrm{Li}_{2} \mathrm{O}\right)$ and a $\mathrm{Li}-\mathrm{O}_{\mathrm{B}}$ correlation $\sim 2.09 \AA(\mathrm{CN}=0.9) .{ }^{49}$ The MD simulations therefore report a shorter metal- $\mathrm{O}_{\mathrm{B}}$ distance for both $\mathrm{Na}$ and $\mathrm{Li}$ ions.

Fig. 5(a)-(d) shows the solid state ${ }^{7} \mathrm{Li},{ }^{23} \mathrm{Na},{ }^{31} \mathrm{P}$ and ${ }^{29} \mathrm{Si}$ MAS NMR, respectively. The ${ }^{7} \mathrm{Li}$ MAS NMR data (see Fig. 5(a)) is represented by single resonances centred at $0.51 \mathrm{ppm}$ and $0.37 \mathrm{ppm}$ for the ${ }^{\mathrm{NaLi}}$ Bio and ${ }^{\mathrm{Li}}$ Bio glasses, respectively. The results are in agreement with ${ }^{7} \mathrm{Li}$ NMR studies by Gee et al. where a chemical shift of $0.47 \mathrm{ppm}$ was reported for mixed $\mathrm{Na}$-Li-silicates. ${ }^{50}$ The introduction of $\mathrm{Na}$ to this system shifts the resonances due to next nearest neighbour effects $(\mathrm{Na}-\mathrm{O}-\mathrm{Li})$, however a minimal effect on the measured nearest neighbour ( $\mathrm{Li}-\mathrm{O}$ ) bond lengths is observed (see Table 4). This chemical shift confirms that the alkali metals are mixed in the glass forming $\mathrm{Na}-\mathrm{O}-\mathrm{Li}$ correlations and not phase separated forming solely $\mathrm{Li}-\mathrm{O}-\mathrm{Li}$ correlations.
The ${ }^{23} \mathrm{Na}$ MAS NMR data of Fig. 5(b) are represented by single featureless resonances that preclude any detailed insight into the $\mathrm{Na}$ speciation that characterises these systems. The simulation of the ${ }^{23} \mathrm{Na}$ data in Fig. 5(b) demonstrates that these species reside in disordered environments, with characteristic tailing of each resonance to high field clearly describing a distribution of field gradients for each glass system. The results of these simulations are summarised in Table 3 , with significant differences in the $\delta_{\text {iso }}$ values for these glasses being measured $\left(\delta_{\text {iso }} 7.12 \mathrm{ppm}\right.$ for ${ }^{\mathrm{Na}} \mathrm{Bio}$ and $\delta_{\text {iso }} 4.06 \mathrm{ppm}$ for ${ }^{\mathrm{NaLi}} \mathrm{Bio}$ ). This upfield shift difference is attributed to an increase in system electronegativity concomitant with $\mathrm{Li}$ incorporation. In contrast, the ${ }^{23} \mathrm{Na}$ 3QMAS (see Fig. 5(e)) clearly suggests that more than one $\mathrm{Na}$ species is present in each bioglass. The $F 1$ projection spectrum for the ${ }^{\mathrm{NaLi}} \mathrm{Bio}$ system shows three partially resolved resonances in the triple quantum dimension; i.e. one very broad and more diffuse lineshape situated beneath two much narrower resonances. These narrower resonances are not resolved in the $F 2$ dimension. The two narrower resonances for the ${ }^{\mathrm{NaLi}} \mathrm{Bio}$ system may be emerging from differences in the average $\mathrm{Na}-\mathrm{O}$ bond distances associated with $\mathrm{Na}-\mathrm{O}_{\mathrm{B}}$ and $\mathrm{Na}-\mathrm{O}_{\mathrm{NB}}$ dominated environments, and thus is consistent with the neutron diffraction structural parameters given in Table 2 describing more

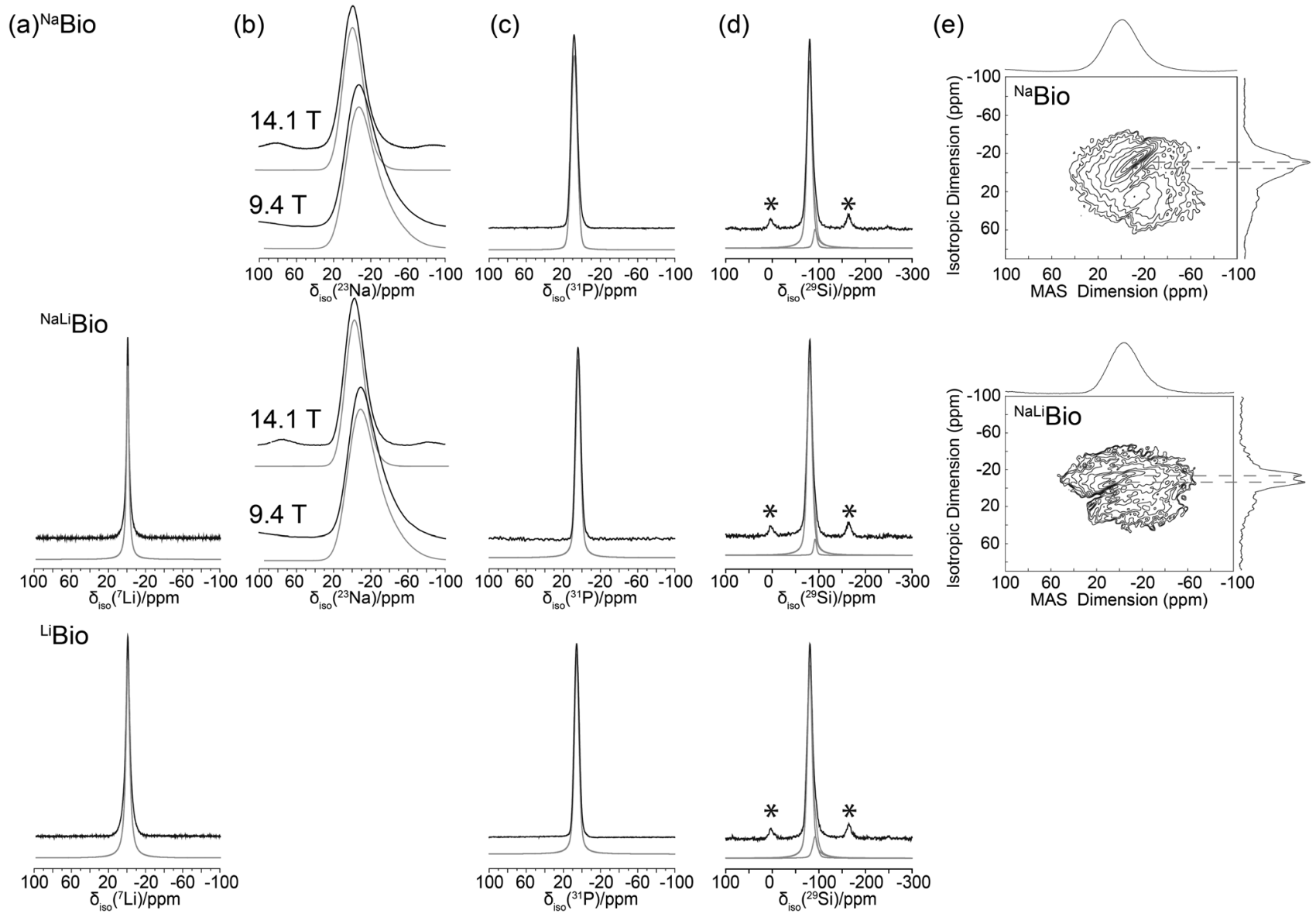

Fig. 5 Solid state MAS NMR data for, (a) one pulse ${ }^{7} \operatorname{Li}$ MAS $(27.5 \mathrm{kHz})$ resonances with spectral simulation shown in grey, (b) variable $B_{0}{ }^{23} \mathrm{Na}$ MAS study with their respected spectral simulations also given in grey, (c) the ${ }^{31} \mathrm{P}$ spectra and its simulations in grey, (d) ${ }^{29} \mathrm{Si}$ study demonstrating the deconvolution into $\mathrm{Q}^{2}$ and $\mathrm{Q}^{3}$ components (* spinning sidebands) and (e) shows the ${ }^{23} \mathrm{Na} 3 \mathrm{QMAS}(12.5 \mathrm{kHz})$ with their respective projections along the isotropic dimension. 
Table 3 Multinuclear solid state MAS NMR parameters achieved from the spectral simulations shown in Fig. 5

\begin{tabular}{|c|c|c|c|c|c|c|c|c|c|c|}
\hline Bioglass & $\begin{array}{l}\delta_{\text {iso }} / \mathrm{ppm} \\
\pm 0.05\end{array}$ & $\begin{array}{l}\delta_{\text {iso }} / \mathrm{ppm} \\
\pm 0.25 \\
\end{array}$ & $\begin{array}{l}C_{\mathrm{Q}} \text { centre } \\
\pm 0.50\end{array}$ & $\begin{array}{l}\text { MHz Width } \\
\pm 0.50\end{array}$ & $\begin{array}{l}\eta_{\mathrm{Q}} \\
\pm 0.10 \\
\end{array}$ & $\begin{array}{l}\delta_{\text {iso }} / \mathrm{ppm} \\
\pm 0.25 \\
\end{array}$ & $\begin{array}{l}\text { Environment } / \% \\
\pm 3\end{array}$ & $\begin{array}{l}\delta_{\text {iso }} / \mathrm{ppm} \\
\pm 0.25 \\
\end{array}$ & $\begin{array}{l}\text { Environment } / \% \\
\pm 3\end{array}$ & $\begin{array}{l}\delta_{\text {iso }} / \mathrm{ppm} \\
\pm 0.25 \\
\end{array}$ \\
\hline Nucleus & ${ }^{7} \mathrm{Li}$ & ${ }^{23} \mathrm{Na}$ & ${ }^{23} \mathrm{Na}$ & ${ }^{23} \mathrm{Na}$ & ${ }^{23} \mathrm{Na}$ & ${ }^{29} \mathrm{Si}$ & ${ }^{29} \mathrm{Si}$ & ${ }^{29} \mathrm{Si}$ & ${ }^{29} \mathrm{Si}$ & ${ }^{31} \mathrm{P}$ \\
\hline${ }^{\mathrm{Na}} \mathrm{Bio}$ & & 7.12 & 6.32 & 5.02 & 0.1 & -79.9 & $\mathrm{Q}^{2} / 90$ & -94.1 & $\mathrm{Q}^{3} / 10$ & 8.0 \\
\hline${ }^{\mathrm{NaLi}}$ Bio & 0.51 & 4.06 & 5.74 & 5.10 & 0.1 & -80.1 & $\mathrm{Q}^{2} / 91$ & -93.8 & $\mathrm{Q}^{3} / 9$ & 4.1 \\
\hline${ }^{\mathrm{Li}} \mathrm{BiO}$ & 0.37 & & & & & -80.4 & $\mathrm{Q}^{2} / 84$ & -94.0 & $\mathrm{Q}^{3} / 16$ & 5.6 \\
\hline
\end{tabular}

than one $\mathrm{Na}$ environment. Conversely, the ${ }^{23} \mathrm{Na} 3 \mathrm{QMAS}$ data from the ${ }^{\mathrm{Na}} \mathrm{Bio}$ system shows that much less resolution is afforded in the $F 1$ projection spectrum, although narrower resonances can still be discerned from the broader, more diffuse resonance.

Utilizing the results of both isomorphic substitution and NMR, it is now possible to return to the $T(r)$ (see Fig. 3) and fit the complex overlapping correlations. The short-range order comprises $\sim 4$ oxygens around $\mathrm{Si}$ at $\sim 1.62 \AA$ and $\sim 4$ oxygen around $\mathrm{P}$ at a separation of between 1.5 and $1.6 \AA$, depending on whether the $\mathrm{P}-\mathrm{O}$ are bridging or non-bridging (also referred to as terminal). ${ }^{51}$ It is important to note that the first peak in $T(r)$ comprising both the $\mathrm{P}-\mathrm{O}$ and $\mathrm{Si}-\mathrm{O}$ correlations is dominated by the $\mathrm{Si}-\mathrm{O}$ correlation. Due to the low concentration of phosphorous present in these glasses the weighting factor for the $\mathrm{Si}-\mathrm{O}$ correlation is more than seven times greater than the $\mathrm{P}-\mathrm{O}$ weighting factor (Table 1). Thus whilst errors associated with the real-space distance, $r$, are typically $\pm 0.02 \AA$ the error associated with $r_{\mathrm{P}-\mathrm{O}}$ is much greater. In this case it is therefore not possible to accurately determine the $r_{\mathrm{P}-\mathrm{O}}$ distance or assign it to bridging or nonbridging $\mathrm{P}$, using diffraction. Instead ${ }^{31} \mathrm{P}$ MAS NMR (discussed below) is used to determine the ratio of bridging and non-bridging $\mathrm{P}$.

The intermediate range order in the range $2.1-2.8 \AA$ consists of overlapping $\mathrm{Na}-\mathrm{O}$ (and/or $\mathrm{Li}-\mathrm{O}$ ), $\mathrm{Ca}-\mathrm{O}, \mathrm{O}-(\mathrm{P})-\mathrm{O}$ and $\mathrm{O}-(\mathrm{Si})-\mathrm{O}$ correlations and it is therefore not usually possible to resolve these unambiguously. However, by accurately determining the $\mathrm{Na}-\mathrm{O}$ (and $\mathrm{Li}-\mathrm{O}$ ) correlations using the first order difference method, the remaining region is simplified and requires only $\mathrm{Ca}-\mathrm{O}$ and $\mathrm{O} \cdots \mathrm{O}$ correlations to be fitted. Furthermore, it is possible to estimate a priori the most probable $\mathrm{O} \cdots \mathrm{O}$ correlations: the $\mathrm{O}-(\mathrm{P})-\mathrm{O}$ and $\mathrm{O}-(\mathrm{Si})-\mathrm{O}$ are both tetrahedrally coordinated, therefore the $\mathrm{O}-(\mathrm{X})-\mathrm{O}$ is given by $\sqrt{8 / 3} r_{\mathrm{X}-\mathrm{O}}$, where $\mathrm{X}$ represents $\mathrm{P}$ or $\mathrm{Si}$. The concentration of $\mathrm{Si}$ is $\sim 10$ times greater than the concentration of $\mathrm{P}$; the $\mathrm{O} \cdots \mathrm{O}$ correlation can therefore be modelled using a single $\mathrm{O} \cdots \mathrm{O}$ correlation that is largely determined by the $\mathrm{O}-(\mathrm{Si})-\mathrm{O}$ term.

The O $\cdots \mathrm{O}$ correlation can be calculated using network connectivity models and confirmed using NMR data. For a silicate glass the network connectivity, $\mathrm{NC}$, is given by

$$
\mathrm{NC}=4-2 Z,
$$

where $Z$, the number of excess oxygen per $\mathrm{SiO}_{2}$, is given by

$$
Z=\frac{c_{\mathrm{O}}}{c_{\mathrm{Si}}}-2
$$

where $c_{\mathrm{O}}$ and $c_{\mathrm{Si}}$ represent the concentration of oxygen and silicon respectively.
The addition of $\mathrm{P}$ complicates the connectivity slightly since $\mathrm{P}$ does not behave in an identical manner to $\mathrm{Si}$ and eqn (9) cannot therefore be modified simply by substituting $c_{\mathrm{Si}}+c_{\mathrm{P}}$ for $c_{\mathrm{Si}}$. For a phosphate-based glass, $\mathrm{NC}=3-y$, where $y$, the number of excess $\mathrm{O}$ per $\mathrm{P}_{2} \mathrm{O}_{5}$, is given by $y=2 c_{\mathrm{O}} / c_{\mathrm{P}}-5$. $^{52,53}$ The fact that $\mathrm{P}$ is present in relatively small amounts in the glass effectively mitigates the complexities this introduces.

The ${ }^{31} \mathrm{P}$ MAS NMR spectra (Fig. 5(c)) shows an average resonance at $\delta_{\text {iso }} \sim 6(2)$ ppm representing $\mathrm{Q}^{0}$ species which are essentially isolated $\mathrm{PO}_{4}$ units present throughout the structure. Note, $\mathrm{Q}^{1}$ and $\mathrm{Q}^{2}$ resonances are expected to occur at $\sim-6 /-8$ and $-22 /-24$ ppm respectively. ${ }^{54}$ There is no evidence of covalent $\mathrm{Si}-\mathrm{O}-\mathrm{P}$ linkages as suggested by the absence of a significant ${ }^{31} \mathrm{P}$ MAS sideband structure that would invoke the substantial chemical shift anisotropy expected from such environments. This suggests that phosphorous does not enter the network and instead remains in distinct orthophosphate, $\mathrm{PO}_{4}$, units. Although there is an observable shift difference between the ${ }^{\mathrm{Na}} \mathrm{Bio}$ and the ${ }^{\mathrm{NaLi}-\mathrm{Li}} \mathrm{Bio}$. This can be attributed to the previously mentioned increase in electronegativity of $\mathrm{Li}$ cation when compared to $\mathrm{Na}$. In this case, since each phosphorous atom is surrounded by 4 non-bridging oxygen atoms, the number of excess oxygen atoms per $\mathrm{SiO}_{2}$ is reduced accordingly and eqn (9) becomes

$$
Z^{\prime}=\frac{c_{\mathrm{O}}-4 c_{\mathrm{P}}}{c_{\mathrm{Si}}}-2
$$

In this case, $c_{\mathrm{O}}, c_{\mathrm{Si}}$ and $c_{\mathrm{P}}$ are $0.552,0.163$ and 0.018 respectively. Therefore, $Z^{\prime}=0.944$ and the network connectivity of the glass is equal to 2.11 . This corresponds to $11 \%$ of the $\mathrm{Si}$ occupying $\mathrm{Q}^{3}$ connectivity and $89 \%$ occupying $\mathrm{Q}^{2}$ connectivity. The experimental ${ }^{29} \mathrm{Si}$ NMR data (see Fig. 5(d)) show asymmetric resonances which can be deconvolved into two Gaussian/Lorentzian (1:1) components located at $\delta \sim$ -80 and -94 ppm; these are assigned to $Q^{2}$ and $Q^{3}$ units, respectively. The resultant simulations of these data yield $\mathrm{Q}^{3}$ abundances of 10,9 and $16 \%$ for the ${ }^{\mathrm{Na}} \mathrm{Bio},{ }^{\mathrm{NaLi}} \mathrm{Bio}$ and the ${ }^{\mathrm{Li}}$ Bio respectively, with the balance of the $\mathrm{Si}$ speciation occupying a $\mathrm{Q}^{2}$ environment. The experimental data is thus in reasonable agreement with the theoretical values provided above (within experimental uncertainties). Knowledge of the $\mathrm{Q}$ speciation allows the average $\mathrm{O} \cdots \mathrm{O}$ coordination number to be calculated. A bridging $\mathrm{O}$ atom has six next nearest neighbour $\mathrm{O}$ atoms whilst a non-bridging $\mathrm{O}$ has only three next nearest neighbour $\mathrm{O}$ atoms, thus a $\mathrm{Si}$ atom having a $\mathrm{Q}$ speciation of $\mathrm{Q}^{2}$ or $\mathrm{Q}^{3}$ will have $\mathrm{O} \cdots \mathrm{O}$ coordination numbers of 4 and 4.8 respectively. It can therefore be calculated that the average $\mathrm{O}-(\mathrm{Si})-\mathrm{O}$ coordination number associated with the samples discussed herein is 4.09. Taking the small concentration of $\mathrm{P}$ into account, which is in an orthophosphate 
Table 4 Structural parameters obtained by fitting the total diffraction patterns, $T(r)$, given in Fig. 3

\begin{tabular}{|c|c|c|c|c|c|c|c|c|c|}
\hline & \multicolumn{4}{|l|}{${ }^{\mathrm{Na}} T(r)$} & \multicolumn{3}{|l|}{${ }^{\mathrm{NaLi}} T(r)$} & \multicolumn{2}{|l|}{${ }^{\mathrm{Li}} T(r)$} \\
\hline & $r(\AA)( \pm 0.02)$ & $N( \pm 0.2)$ & $\sigma(\AA)( \pm 0.04)$ & $r(\AA)( \pm 0.02)$ & $N( \pm 0.2)$ & $\sigma(\AA)( \pm 0.04)$ & $r(\AA)( \pm 0.02)$ & $N( \pm 0.2)$ & $\sigma(\AA)( \pm 0.04)$ \\
\hline $\mathrm{P}-\mathrm{O}$ & 1.60 & 4.1 & 0.03 & 1.60 & 3.9 & 0.04 & 1.60 & 3.9 & 0.05 \\
\hline $\mathrm{Si}-\mathrm{O}$ & 1.62 & 3.9 & 0.07 & 1.62 & 3.9 & 0.07 & 1.62 & 3.9 & 0.07 \\
\hline $\mathrm{Li}-\mathrm{O}$ & - & - & - & 1.94 & 3.0 & 0.15 & 1.96 & 3.0 & 0.15 \\
\hline $\mathrm{Li}-\mathrm{O}$ & - & - & - & 2.26 & 1.7 & 0.17 & 2.26 & 1.6 & 0.20 \\
\hline $\mathrm{Na}-\mathrm{O}$ & 2.30 & 3.0 & 0.16 & 2.32 & 3.0 & 0.16 & - & - & - \\
\hline $\mathrm{Na}-\mathrm{O}$ & 2.64 & 1.5 & 0.10 & 2.66 & 1.7 & 0.14 & - & - & - \\
\hline $\mathrm{Ca}-\mathrm{O}$ & 2.36 & 5.3 & 0.10 & 2.36 & 5.3 & 0.11 & 2.36 & 5.3 & 0.13 \\
\hline $\mathrm{O}-\mathrm{O}$ & 2.65 & 4.1 & 0.11 & 2.65 & 4.0 & 0.11 & 2.65 & 4.1 & 0.11 \\
\hline $\mathrm{Ca}-\mathrm{O}$ & 2.72 & 1.2 & 0.17 & 2.73 & 1.4 & 0.15 & 2.74 & 1.2 & 0.19 \\
\hline
\end{tabular}

environment with a corresponding average $\mathrm{O}-(\mathrm{P})-\mathrm{O}$ coordination number of 3 , the overall average $\mathrm{O} \cdots \mathrm{O}$ coordination number of these glasses is therefore estimated to be 3.98 . The $\mathrm{O} \cdots \mathrm{O}$ peak position is expected to occur at $\sim 2.65 \AA$, given that $r_{\mathrm{O}-(\mathrm{Si})-\mathrm{O}}=\sqrt{8 / 3} r_{\mathrm{Si}-\mathrm{O}}$, where $r_{\mathrm{Si}-\mathrm{O}}$ is $1.62 \AA$. Thus, the complex region containing overlapping $\mathrm{Ca}-\mathrm{O}, \mathrm{Na}-\mathrm{O}$, $\mathrm{O}-(\mathrm{P})-\mathrm{O}$ and $\mathrm{O}-(\mathrm{Si})-\mathrm{O}$ correlations has effectively been further simplified and can now be modelled using the experimentally determined $\mathrm{Na}-\mathrm{O}$ (or $\mathrm{Li}-\mathrm{O}$ ) input parameters and the $\mathrm{O}-(\mathrm{P})-\mathrm{O}$ and $\mathrm{O}-(\mathrm{Si})-\mathrm{O}$ parameters derived above and confirmed using NMR. The only truly unknown feature remaining in this region of the total diffraction pattern (i.e. $r<2.8 \AA$ ) is the $\mathrm{Ca}-\mathrm{O}$ correlation.

The fitting parameters for the total diffraction patterns are given in Table 4, and the overall fit is given in Fig. 3 (solid curve). The $\mathrm{O} \cdots \mathrm{O}$ coordination number is consistent with the model outlined above and with recent results given for $\mathrm{Ca} / \mathrm{Sr}$ bioglass. Hitherto, it has proven difficult to de-convolve diffraction data reliably to estimate the overlapping $\mathrm{Na}-\mathrm{O}$, $\mathrm{Ca}-\mathrm{O}$ and $\mathrm{O} \cdots \mathrm{O}$ correlations; in the absence of additional information, such as that reported here, this resulted in the assumption of a single $\mathrm{Na}-\mathrm{O}$ correlation and the underestimation of the $\mathrm{O} \cdots \mathrm{O}$ coordination number. ${ }^{26}$

The $\mathrm{Ca}-\mathrm{O}$ values presented in Table 4 are in excellent agreement with recently reported values obtained using an isomorphic substitution of $\mathrm{Sr}$ for $\mathrm{Ca}$ where $\mathrm{Ca}-\mathrm{O}_{\mathrm{NB}}$ and $\mathrm{Ca}-\mathrm{O}_{\mathrm{B}}$ distances of $\sim 2.36 \AA$ and $2.72 \AA$ were reported. ${ }^{31}$ The values are consistent with crystalline $\mathrm{Na}_{2} \mathrm{CaSi}_{2} \mathrm{O}_{6}$ for which $\mathrm{Ca}-\mathrm{O}$ values in the range $2.32-2.72 \AA$ are reported. ${ }^{46}$ Interestingly, the substitution of $\mathrm{Na}$ with $\mathrm{Li}$ does not appear to significantly influence the local $\mathrm{Ca}-\mathrm{O}$ environment. This is important since previous results suggested that $\mathrm{Na}-\mathrm{Ca}$ silicate glasses show a non-random distribution of cations, with a preference for $\mathrm{Ca}-\mathrm{O}-\mathrm{Na}$ bonds at the expense of $\mathrm{Ca}-\mathrm{O}-\mathrm{Ca}$ and $\mathrm{Na}-\mathrm{O}-\mathrm{Na}$ bonds. ${ }^{30}$ It may therefore also be expected that a preference for $\mathrm{Ca}-\mathrm{O}-\mathrm{Li}$ bonds may exist.

In contrast, in sol-gel analogues containing no $\mathrm{Na}^{+}$ (or $\mathrm{Li}^{+}$) but which do contain significant levels of $\mathrm{H}^{+}$, an additional $\mathrm{Ca}-\mathrm{O}$ correlation at $\sim 2.5 \AA$ is found which is assigned to $\mathrm{Ca}-\mathrm{OH}{ }^{5,55}$ Whilst hydroxyl groups are broadly assumed to play a similar structural role in sol-gel derived bioactive glasses to that of $\mathrm{Na}$ (or $\mathrm{Li}$ ) in melt quench glasses (i.e. provide a route for incorporating additional oxygen atoms to break up the silica network connectivity and to provide a small monovalent ion that easily leaches from the glass under aqueous/physiological conditions), it appears - $\mathrm{OH}$ has a much more pronounced effect on the local environment surrounding the calcium ions.

Solubility (and therefore bioactivity) of these glasses is controlled by 3 key factors. The average network connectivity determined by the oxygen to silicon ratio (eqn (8) and (9)) is the most important parameter. The second term relates to the valency of the modifying ions such that monovalent systems are more soluble than divalent systems, i.e. a sodium silicate will be more soluble than a calcium silicate with the same network connectivity. Finally the cation size influences the solubility due to the expansion of the glass matrix. Although the network and short range order (e.g. $\mathrm{Si}-\mathrm{O}$ and $\mathrm{O}-\mathrm{Si}-\mathrm{O})$ are not significantly affected by the alkali ion substitution the increase in cation size expands the matrix through longer $\mathrm{Na}-\mathrm{O}$ correlations compared to $\mathrm{Li}-\mathrm{O}$ correlations. The expanded $\mathrm{O}-\mathrm{Na}-\mathrm{O}$ correlations compared to the $\mathrm{O}-\mathrm{Li}-\mathrm{O}$ correlations will result in a more open structure which will increase the rate of dissolution. Analogous results have been reported when $\mathrm{Sr}$ is substituted for $\mathrm{Ca}$ within bioactive glasses. ${ }^{56}$ Note the mechanism for dissolution will not apply to sol-gel derived glasses due to the much wider $\mathrm{Q}^{n}$ distribution and silanol groups present. ${ }^{57}$ Therefore glasses containing $\mathrm{H}^{+}$would dissolve faster than equivalent $\mathrm{Li}^{+}$or $\mathrm{Na}^{+}$glasses.

The key assumption underpinning the isomorphic substitution method employed is that the short range order pair correlations not containing the isomorphs, in this case $\mathrm{Na}$ / $\mathrm{Li}$, are not significantly affected by the substitution and that these correlations therefore successfully cancel during the formation of the first order difference function. As shown in Table 3, the correlations not containing $\mathrm{Na}$ or $\mathrm{Li}$ are consistent for each of the three total diffraction patterns. It is apparent from the fitting parameters returned that the model is fully self-consistent between the experimental values for the first order difference functions, the total diffraction data, the solid state MAS NMR data and theory.

\section{Conclusions}

The diffraction data presented and discussed above affords a detailed structural model of the local and intermediate range order in bioactive glasses wherein the study of the $\mathrm{Na}$ site is made more tractable by substituting Li for $\mathrm{Na}$ within these systems. The conclusions drawn from diffraction studies are strongly supported by the complementary NMR data. The assumption that isomorphic substitution could be employed to determine the short range order of $\mathrm{Na}$ and Li bioactive glasses 
is thereby verified. The $\mathrm{Na}-\mathrm{O}$ environment for the present melt-quench glass was found to be very disordered and was best modelled using two $\mathrm{Na}-\mathrm{O}$ correlations centred at $2.31 \AA$ and $2.65 \AA$. This provides the first direct experimental evidence of a split $\mathrm{Na}-\mathrm{O}$ correlation in Bioglass and supports existing molecular dynamics simulations. The substitution of $\mathrm{Na}$ with $\mathrm{Li}$ does not appear to affect the $\mathrm{Ca}-\mathrm{O}$ local environment. Bioglass is a complex glass system, containing 5 separate elements and therefore 15 overlapping pair correlation functions: the present study therefore represents one of the most detailed studies undertaken on any complex glassy system and has resulted in the characterization of the short and intermediate range order.

\section{Acknowledgements}

This work was supported by EPSRC grants EP/E050611/1 and EP/E051669/1. The authors wish to thank the STFC for the provision of beam-time at the ISIS pulsed neutron source. We wish to acknowledge the use of the Chemical Database Service at Daresbury. RAM acknowledges the Royal Society for the Research Grant RG100147. JVH and MES acknowledge the continued funding of the 300,400 and $600 \mathrm{MHz}$ instrumentation used in this research which was facilitated by EPSRC, the University of Warwick and partial funding through Birmingham Science City Advanced Materials Projects 1 and 2 supported by Advantage West Midlands (AWM) and the European Regional Development Fund (ERDF).

\section{References}

1 L. L. Hench, R. J. Splinter, W. C. Allen and T. K. Greenlee, J. Biomed. Mater. Res. Symp., 1971, 5, 25.

2 A. E. Clark, L. L. Hench and H. A. Paschall, J. Biomed. Mater. Res., 1976, 10, 161.

3 L. L. Hench, J. Mater. Sci. Mater. Med., 2006, 17, 967.

4 L. L. Hench, W. June and D. C. Greenspan, J. Australas. Ceram. Soc., 2004, 40, 1.

5 L. J. Skipper, F. E. Sowrey, D. M. Pickup, K. O. Drake, M. E. Smith, P. Saravanapavan, L. L. Hench and R. J. Newport, J. Mater. Chem., 2005, 15, 2369.

6 L. L. Hench and I. Thompson, J. R. Soc. Interface, 2010, 7, S379.

7 R. A. Martin, H. Twyman, D. Qiu, J. C. Knowles and R. J. Newport, J. Mater. Sci. Mater. Med., 2009, 20, 883.

8 F. J. Zhang, M. W. A. Skoda, R. M. J. Jacobs, R. A. Martin, C. M. Martin and F. Schreiber, J. Phys. Chem. B, 2007, 111, 251.

9 L. Ianeselli, F. J. Zhang, M. W. A. Skoda, R. M. J. Jacobs, R. A. Martin, S. Callow, S. Prevost and F. Schreiber, J. Phys. Chem. B, 2010, 114, 3776 .

10 I. Ahmed, M. Lewis, I. Olsen and J. C. Knowles, Biomaterials, 2004, 25, 491 .

11 I. D. Xynos, A. J. Edgar, L. D. K. Buttery, L. L. Hench and J. M. Polak, J. Biomed. Mater. Res., 2001, 55, 151.

12 Y. Minaberry and M. Jobbagy, Chem. Mater., 2011, 23, 2327.

13 I. Izquierdo-Barba, D. Arcos, Y. Sakamoto, O. Terasaki, A. López-Noriega and M. A. Vallet-Regí, Chem. Mater., 2008, 20, 3191.

14 J. Román, S. Padilla and M. Vallet-Regí, Chem. Mater., 2003, 15, 798.

15 D. Arcos, D. C. Greenspan and M. Vallet-Regi, Chem. Mater., $2002, \mathbf{1 4}, 1515$.

16 P. Sepulveda, J. R. Jones and L. L. Hench, J. Biomed. Mater. Res., 2002, 59, 340 .

17 V. FitzGerald, R. A. Martin, J. R. Jones, D. Qiu, K. M. Wetherall, R. M. Moss and R. J. Newport, J. Biomed. Mater. Res., Part A, 2009, 91A, 76.
18 R. A. Martin, S. Yue, J. V. Hanna, P. D. Lee, R. J. Newport, M. E. Smith and J. R. Jones, Philos. Trans. R. Soc. London, Ser. A, 2012, 370, 1422.

19 A. Pedone, T. Charpentier, G. Malavasi and M. C. Menziani, Chem. Mater., 2010, 22, 5644.

20 Y. Xiang and J. Du, Chem. Mater., 2011, 23, 2703.

21 A. Tilocca, A. N. Cormack and N. H. de Leeuw, Chem. Mater., 2007, 19, 95.

22 R. N. Mead and G. Mountjoy, Chem. Mater., 2006, 18, 3956.

23 J. M. Oliveira, R. N. Correia and M. H. Fernandes, Biomaterials, 2002, 23, 371.

24 M. Corno, A. Pedone, R. Dovesi and P. Ugliengo, Chem. Mater., 2008, 20, 5610.

25 A. Tilocca, J. Mater. Chem., 2010, 20, 6848.

26 V. FitzGerald, D. M. Pickup, D. Greenspan, G. Sarkar, J. J. Fitzgerald, K. M. Wetherall, R. M. Moss, J. R. Jones and R. J. Newport, Adv. Funct. Mater., 2007, 17, 3746.

27 E. Kuzielová, M. Palou, J. Lokaj and J. Kozánková, Adv. Appl. Ceram., 2008, 107, 203.

28 I. Elgayar, A. E. Aliev, A. R. Boccaccini and R. G. Hill, J. NonCryst. Solids, 2005, 351, 173.

29 A. Angelopoulou, V. Montouillout, D. Massiot and G. Kordas, J. Non-Cryst. Solids, 2008, 354, 333.

30 S. K. Lee and J. F. Stebbins, J. Phys. Chem. B, 2003, 107, 3141.

31 R. A. Martin, H. Twyman, G. J. Rees, E. R. Barney, R. M. Moss, J. M. Smith, R. G. Hill, G. Cibin, T. Charpentier, M. E. Smith, J. V. Hanna and R. J. Newport, submitted.

32 A. C. Hannon, Nucl. Instrum. Methods Phys. Res., Sect. A, 2005, 551, 88.

33 R. A. Martin, P. S. Salmon, H. E. Fischer and G. J. Cuello, J. Phys.: Condens. Matter, 2003, 15, 8235.

34 R. A. Martin, P. S. Salmon, H. E. Fischer and G. J. Cuello, Phys. Rev. Lett., 2003, 90, 185501.

35 R. K. Harris, E. D. Becker, S. M. C. de Menezes, R. Goodfellow and P. Granger, Solid State Nucl. Magn. Reson., 2002, 22, 458.

36 J.-P. Amoureux, C. Fernandez and S. Steuernagel, J. Magn. Reson., Ser. A, 1996, 123, 116.

37 M. E. Smith and E. R. H. van Eck, Prog. Nucl. Magn. Reson. Spectrosc., 1999, 34, 159.

38 R. M. Moss, PhD thesis, University of Kent, 2009.

39 I. D. Brown and D. Altermatt, Acta Crystallogr., Sect. B: Struct. Sci., 1985, 41, 244.

40 A. N. Cormack and J. C. Du, J. Non-Cryst. Solids, 2001, 293, 283.

41 A. Tilocca, J. Chem. Phys., 2008, 129, 084504.

42 G. Malavasi, M. Menziani, A. Pedone, B. Civalleri, M. Corno and P. Ugliengo, Theor. Chem. Acc., 2007, 117, 933.

43 A. Tilocca, N. H. de Leeuw and A. N. Cormack, Phys. Rev. B. Condens. Matter Mater. Phys., 2006, 73, 104209.

44 N. M. Vedishcheva, B. A. Shakhmatkin, M. M. Shultz, B. Vessal, A. C. Wright, B. Bachra, A. G. Clare, A. C. Hannon and R. N. Sinclair, J. Non-Cryst. Solids, 1995, 193, 292.

45 B. Vessal, A. C. Wright and A. C. Hannon, J. Non-Cryst. Solids, 1996, 196, 233.

46 H. Ohsato, I. Maki and Y. Takeuchi, Acta Crystallogr., Sect. C: Cryst. Struct. Commun., 1985, 41, 1575.

47 A. Pedone, G. Malavasi and M. C. Menziani, J. Phys. Chem. C, 2009, 113, 15723.

48 K. F. Hesse, Acta Crystallogr., Sect. B: Struct. Sci., 1977, 33, 901.

49 A. Pedone, G. Malavasi, A. N. Cormack, U. Segre and M. C. Menziani, Chem. Mater., 2007, 19, 3144.

50 B. Gee, M. Janssen and H. Eckert, J. Non-Cryst. Solids, 1997, 215, 41.

51 U. Hoppe, G. Walter, A. Barz, D. Stachel and A. C. Hannon, J. Phys.: Condens. Matter, 1998, 10, 261.

52 R. A. Martin, P. S. Salmon, C. J. Benmore, H. E. Fischer and G. J. Cuello, Phys. Rev. B: Condens. Matter Mater. Phys., 2003, 68, 054203.

53 R. A. Martin, P. S. Salmon, H. E. Fischer and G. J. Cuello, J. NonCryst. Solids, 2004, 345-346, 208.

54 D. Carta, D. M. Pickup, J. C. Knowles, I. Ahmed, M. E. Smith and R. J. Newport, J. Non-Cryst. Solids, 2007, 353, 1759.

55 R. J. Newport, L. J. Skipper, V. FitzGerald, D. M. Pickup, M. E. Smith and J. R. Jones, J. Non-Cryst. Solids, 2007, 353, 1854

56 Y. C. Fredholm, N. Karpukhina, D. S. Brauer, J. R. Jones, R. V. Law and R. G. Hill, J. R. Soc. Interface, 2012, 9, 880.

57 K. Fujikura, N. Karpukhina, T. Kasuga, D. S. Brauer, R. G. Hill and R. V. Law, J. Mater. Chem., 2012, 22, 7395. 